УДК 373.3.091.3:811 (477)(075)

\title{
МЕТОДИЧНІ АСПЕКТИ РОЗВИТКУ ЗВ'ЯЗНОГО МОВЛЕННЯ СТУДЕНТІВ ПІД ЧАС НАПИСАННЯ ТВОРІВ-РОЗДУМІВ
}

\author{
Світлана Помирча \\ кандидат філологічних наук, \\ доцент кафедри теорії і практики початкової освіти \\ ДВНЗ «Донбаський державний педагогічний університет» \\ м. Слов'янськ, Україна \\ ORCID ID 0000-0003-1636-3239 \\ swetlanapom@gmail.com \\ Наталія Громова \\ кандидат педагогічних наук, \\ доцент кафедри української мови, \\ Сумський державний педагогічний університет імені А.С. Макаренка \\ м. Суми, Україна \\ ORCID ID 0000-0002-2784-1016 \\ gromovanv2015@gmail.com
}

\begin{abstract}
Анотація. У статті розглянуто рекомендації щодо написання власного висловлювання у вигляді твору-роздуму. Ці теоретичні методичні поради допоможуть закріпити теоретичні знання на практиці, виробити стійкі вміння i навички щодо написання власного висловлювання за чіткими параметрами, передбаченими умовами написання такого виду творчої роботи.

У статті авторка розглядає етапи написання твору-роздуму; звертає увагу на те, що такий вид роботи дає змогу одночасно оцінити рівень мовної, мовленнєвої і комунікативної компетенції майбутніх учителів.

Уміння сприймати, розуміти почуте або прочитане, викладати його зміст, точно формулювати думку, висловлювати іiі в писемній формі можуть бути сформовані лише на основі розвитку мислення і мовлення, що є основою навчання сучасної української мови у BH3.
\end{abstract}

Ключові слова: розвиток мовлення; твір-роздум; алгоритм написання; текст; тема.

Постановка проблеми. Мовна освіта в Україні спрямована на виховання людини, яка вільно володіє літературною мовою в усіх сферах суспільного життя. Уміння сприймати, розуміти почуте або прочитане, викладати його зміст, точно формулювати думку, висловлювати іiі в усній чи писемній формі можуть бути сформовані лише на основі розвитку мислення і мовлення, що є основою формування професійно-педагогічної компетентності майбутнього вчителя.

Основна мета навчання сучасної української мови, актуальність якої підкреслена в чинних програмах, полягає у формуванні національно свідомої, духовно багатої мовної особистості, яка володіє вміннями й навичками вільно, комунікативно виправдано користуватися засобами рідної мови - iї стилями,

Професіоналізм педагога: теоретичні й методичні аспекти. - Вип. 12. - Слов'янськ, 2020. 


\section{С. ПОМИРЧА, Н. ГРОМОВА}

Методичні аспекти розвитку зв'язного мовлення студентів під час написання творів-роздумів

формами, жанрами в усіх видах мовленнєвої діяльності (слухання, читання, говоріння, письмо), тобто вчити студентів не лише слухати, говорити, читати, а й писати, тобто створювати тексти.

Аналіз останніх досліджень і публікацій. Своєрідність і складність опанування писемним мовленням дослідив психолог Л. Виготський, у роботах якого зазначено, що писемне мовлення вимагає високого ступеня абстракції, це - мовлення подумки, позбавлене матеріального звука, це мовлення без співрозмовника. Психолога хвилює відсутність партнера по діалогу, мовця, який пише. Він виходить із суперечливого становища таким чином: «Той, до кого звернуте мовлення, або відсутній зовсім, або не перебуває в контакті з тим, хто пише. Це - мовлення - монологічна розмова 3 білим аркушем паперу, 3 уявлюваним чи лише умовним співрозмовником» (Виготський, 1999, с. 275).

За Л. Виготським, під час написання тексту-роздуму викладач має враховувати структуру мисленнєвої діяльності студента, а саме: «(студент) має усвідомити звукову структуру слова, розчленити його і вольовим зусиллям відтворити його в письмових знаках» (Виготський, 1999). Психолог також акцентує увагу на писемному мовлення, яке більшою мірою, ніж усне, залежить від волі людини: «Його (студента) синтаксис таким самим чином залежить від волі мовця в писемному мовленні, як і їі фонетика. Нарешті, семантичний лад писемного мовлення так само вимагає вольової роботи над значеннями слів та їхнім розгортанням у певній послідовності, як і синтаксис та фонетика» (Виготський, 1999, с. 278). Отже, плануючи систему письмових творчих робіт на практичних заняттях, пам'ятаємо, що писемне мовлення, за Л. Виготським, «... примушує діяти (студента) більш інтелектуально. Це алгебра мовлення, найбільш важка й складна форма цілеспрямованої та усвідомленої мовленнєвої діяльності» (Виготський, 1999, с. 279 ).

Зв'язне мовлення розглядається в методиці як особлива галузь роботи 3 розвитку мовлення - процес говоріння, діяльність мовця, продукт діяльності, текст, висловлювання. У методичній науці вже склалася певна система проблем у дослідженні розвитку писемного мовлення (О. Біляєв, О. Ішутіна, П. Кордун, Г Ладиженська, М. Пентилюк, М. Рибникова, І. Синиця, С. Чавдаров та ін.).

Питання написання твору розглядали такі українські методисти, як О. Тесля, В. Цимбалюк, Б. Степанишин, Є. Пасічник та інші. Дискусії точаться навколо проблем: «Як навчити писати твори? Як класифікувати твори? Які висунуті вимоги до творів? Наведемо дві позиції щодо «як навчити». Скажімо, T. Донченко, О. Тесля вважають, що найкраще «вчити на зразках, а не на розмірковуваннях, про різні види письмових творів», методист радить демонструвати кращі, зразкові письмові роботи інших (Донченко, 2001). 
Методичні аспекти розвитку зв'язного мовлення студентів під час написання творів-роздумів

Т. Донченко заперечує такий підхід та зазначає, що «гарні твори повинні наче самі виникнути під впливом певних умов, заздалегідь продуманих i підготовлених, а не з'явитися внаслідок вимог чи суто організаційних заходів. Типовий недолік творів - це масове списування та мізерна питома вага власної учнівської творчості» (Донченко, 2001).

Формулювання цілей статті (постановка завдання). Мета роботи полягає в комплексному дослідженні та обгрунтуванні етапів роботи над структурою, методикою написання тексту-роздуму.

Теоретичні основи дослідження. Одним із традиційних видів роботи 3 розвитку зв'язного мовлення студентів $\epsilon$ твір-роздум, що має методичну історію i різнобічне методичне забезпечення. Такий вид роботи, будучи засобом навчання і перевірки знань і вмінь, дає змогу одночасно оцінити рівень мовної, мовленнєвої і комунікативної компетенції майбутніх учителів.

У науковій, методичній $\mathrm{i}$ навчальній літературі останніх років відображається i нове для науки питання, як використовувати в навчанні писемного монологічного зв'язного мовлення текст і його елементи (Ішутіна, 2018; Пентилюк, 2010). Інтерес лінгвістів до питань дослідження тексту відбиває характерну для сучасного етапу розвитку мовознавства тенденцію переходу від навчання мови як абстрактної системи до дослідження іï функціонування як засобу комунікації. Якщо поглянути на твір-роздум під кутом зору визначених у проєкті стандартів мовної освіти та чинних програмах з української мови, то не важко помітити, що цей вид роботи значною мірою відповідає сучасним вимогам, бо дає змогу організувати навчання зв'язного мовлення за типом діяльності (Митяй, 2012). Як відомо, твір-роздум - це зв'язний текст, у якому в логічній послідовності передаються думки, міркування як доказ чи пояснення чогось, робляться відповідні висновки.

Зазначимо, що будь-який вид людської діяльності, творча праця розвивається за певною логікою, тобто складається 3 послідовності взаємопов'язаних етапів, де успішність реалізації кожного попереднього визначає результативність наступного. I навпаки, проходження якогось етапу похапцем, здійснення його нашвидку може не лише ускладнити роботу на наступних етапах, а інколи й унеможливлювати їхню реалізацію взагалі. Тому на шляху навчання мистецтву створення творів-роздумів теж варто рухатися за певною логікою, послідовно набираючи суму необхідних знань, щоб сформулювати стійкі вміння й навички застосування їх на практиці.

Отже, окреслімо етапи написання власних висловлень (творів-роздумів) i надалі послідовно їх проаналізуємо.

Етапи написання твору-роздуму.

Професіоналізм педагога: теоретичні й методичні аспекти. - Вип. 12. - Слов'янськ, 2020. 
1. Підготовка до написання твору-роздуму.

2. Аналіз теми твору.

3. Формування власної позиції щодо теми.

4. Попереднє конструювання твору (алгоритмізація).

5. Послідовне написання частин твору.

6. Аналіз написаного (переказування).

7. Перевірка мовного оформлення написаного.

8. Переписування твору на чистовик і можливе редагування.

9. Остаточна перевірка твору.

На підступах до написання твору-роздуму стануть у пригоді такі вміння:

- знаходити в схованках пам'яті або пропонувати власні тлумачення слів;

- виявляти «внутрішню» форму слів;

- визначати походження слів (етимологію);

- добирати до слів синоніми, антоніми тощо;

- уводити слова в нові контексти;

- вигадувати до слів рими;

- поєднувати слова в асоціативні ряди;

- трансформувати речення;

- перефразовувати речення, спрощувати їх тощо.

Наведемо низку вправ, у яких слово «роздумувати» розкриється студентам iз різних боків та здивує своєю глибиною й уплетеністю в системі інших слів мови тощо.

1. Доберіть однокореневі слова до слова «роздумувати» (думати, думка, дума, ум, розум, розуміти).

2. Побудуйте синонімічний ряд: роздумувати, розмірковувати, думу думати, займатися розмислами, заглибитися в думу, варити кашу в глечику (голові) та подумайте, у чому різниця між значеннями цих слів.

3. Уведіть слово «роздумувати» в ряд слів із спільним префіксом роз-: (роздумувати, розмірковувати, розгойдувати, розказувати, розкидати). Як бачимо, за допомогою цього префікса в словах з'являється значення: «робити щось»: 1) методично (ніби міряємо міркою щось); 2) послідовно (ніби маятник розгойдується); 3) неквапливо (як ніби бабуся казку каже); 4) урізнобіч і всебічно (як ніби по колу сіється пшениця) - і в такий спосіб з'явиться глибше й простіше розуміння слова «роздумувати».

На наступному занятті радимо студентам пограти «в риму», в асоціації, покаламбурити, наприклад, зі словом «фахівець»:

1. Доберіть до цього слова всі можливі рими: фахівець, холодещь, молодещь, $x т о с ь$, десь тощо, а потім запропонувати скласти римований віршик. 
Методичні аспекти розвитку зв'язного мовлення студентів під час написання творів-роздумів

2. Не задумуючись, швидко назвіть все (слова, фрази), що виникає у свідомості до слова «мама»: матусенька, ненька (синоніми), рідна, тепла, красива, люба (означення), тато (антонім), дім, радість, їжа, уроки, чекати, сердитися, примушувати, хвалити (стереотипи щодо функції удома), «Рідна мати моя, ти ночей не доспала...» (типова реакція на питання, яку пісню знаєте про маму) і подібне. Як не дивно, проте всі ці слова й фрази не випадкові, знаходяться в так званих групах за тематикою, сферою використання. «Граючи» зі словами, варто пам'ятати, що, підступаючи до написання твору, студентові так само треба починати з асоціацій, щойно побачивши запропоновану тему твору.

Пропонуємо студентам провести міні-експеримент. Доберіть до теми «Дружба - це важка робота» все, що виникає, - розумне й неважливе, доречне чи зайве, уривками й цілісно... Після завершення роботи бачимо, що в загальних рисах твір написано.

Під час роботи над «словом» заохочуємо студентів знайти помилки в рекламних оголошеннях, у мовлення сусідів, однокурсників та проаналізувати, яка це помилка, чому вона могла з'явитися. Такі вправи сформують навички i вміння бачити власні огріхи та помилки, що важливо під час написання твору.

Готуючись до написання творчої роботи, пропонуємо студентам «пограти» 3 реченнями, трансформуючи їх, якнайглибше проаналізувати їх з різних боків. Це може бути добір синонімічних конструкцій, наприклад: Вивчаючи правила, я стаю розумніший / Коли я вивчаю правила, то стаю розумніший / Вивчення правил робить мене розумнішим / Стаю розумнішим, тому що вивчаю правила / Розумнішаю, бо вивчаю правила / Учу правила - розумнішаю...

Після виконання цього завдання студентам пропонується поміркувати, у чому ж різниця між смислами, що виражаються кожною з конструкцій, чи є вона взагалі?

Наступним етапом перед написанням твору-роздуму $є$ ознайомлення 3 темою, запропонованою для осмислення в тексті. Практика засвідчує, що досить часто ознайомлення 3 темою здійснюється побіжно, наслідком чого стає неадекватне, неналежне іiі розуміння. Пропонуємо студентам виробити в собі вміння зупинятися, фокусуватися на темі, навчитися працювати 3 нею аналізувати, розшифровувати іï, розгадувати приховані в ній варіанти iï розкриття.

Слово «тема» прийшло в українську мову із латинської, де воно означало «положення». До латинської це слово прийшло з грецької, у якій в іншому звучанні означало «ставлю, кладу». У літературознавстві «тема художнього твору» - це те, про що автор розповідає, той фрагмент життя, над яким письменник розмірковує у своєму творі. Отже, тема - це загальний предмет для

Професіоналізм педагога: теоретичні й методичні аспекти. - Вип. 12. - Слов'янськ, 2020. 


\section{С. ПОМИРЧА, Н. ГРОМОВА}

Методичні аспекти розвитку зв'язного мовлення студентів під час написання творів-роздумів

думки будь-кого, а ідея - це те, що саме хтось один може й хоче сказати про цей предмет, спираючись на свої знання, досвід, уміння аналізувати тощо. Для того щоб навчитися бачити «предмет», ретельно працювати 3 темою, почати втілювати «ідею», пропонуємо дотримуватися алгоритму роботи:

- зрозуміти всі слова, які є в темі;

- виявити ії логіку, тобто взаємозв'язки (де причина, а де наслідок, де підстава, а де результат тощо);

- розмежувати головне й другорядне в ній;

- схематизувати іiі, спростити, щоб навіть щонайскладніше формулювання стало прозорим.

Не зробивши цього, не зрозумівши теми, не можна переходити до наступного етапу написання твору - формування власної позиції щодо теми.

Традиційно для написання такого виду творчої роботи є три варіанти формування власної думки:

1. Погодитися цілком із думкою (ідеєю), висловленою в темі.

2. Не погодитися зовсім із думкою, запропонованою в темі.

3. Частково погодитися, а частково не погодитися 3 думкою висловленою в темі.

Найскладнішим, як засвідчує практика, $є$ шлях часткового погодження й часткового заперечення думки, висловленої в темі. Це зумовлене тим, що, поперше, у межах невеликого твору досить важко викласти міркування i «за», i «проти», по-друге, для ведення таких роздумів студент має чітко усвідомлювати, із чим він погоджується, а з чим - ні. Наслідком стає робота, у якій відсутні логіка, послідовність та завершеність думки.

Після належного опрацювання попередніх етапів переходимо до попереднього конструювання (алгоритмізацію), тобто створення своєрідного логічного алгоритму майбутнього твору. Цей вид попередньої роботи важливий 3 огляду на те, що тут студенти мають можливість у загальних рисах намітити основні пункти власних міркувань. Ця конструкція передбачає наявність тези, 2 - 3-х аргументів, прикладів до кожного з аргументів і висновку. Під час побудови конструкції важливо визначитися з розташуванням цих частин твору-роздуму, наскільки логічно підтримують і продовжують одна одну, для того щоб твір набув відповідної цілісності. Розглянемо алгоритм твору, де першою йде теза.

Теза. Я думаю так!

Аргумент 1. Я так думаю, тому що...

Приклад до аргументу 1. Мої міркування найточніше ілюструє такий приклад...

Аргумент 2. Я думаю так ще й тому, що... 
Методичні аспекти розвитку зв'язного мовлення студентів під час написання творів-роздумів

Приклад до аргументу 2. Мій аргумент найточніше може проілюструвати такий приклад...

Загальний висновок. Отже, думка про те, що... послідовно стверджується низкою доказів, які виразно ілюструються прикладами, що дозволяє робити висновок про виправданість мого погляду на...

Наступний алгоритм передбачає таку побудову твору, де компоненти «аргументація» та «приклади» подаються окремими блоками. Схематично цей алгоритм можна представити так:

Теза. Я думаю так!

Аргумент 1. Я так думаю, тому що...

Аргумент 2. Я так думаю, тому ще й тому, що...

Приклади до аргументів 1 i 2. Мої аргументи можна проілюструвати багатьма прикладами. Наведу деякі з них...

Загальний висновок. Отже, думка про те, що... послідовно стверджується низкою доказів, які виразно ілюструються прикладами, що дозволяє робити висновок про виправданість мого погляду на певну проблему чи питання.

П'ятий етап - послідовне написання частин твору, має здійснюватися 3 чітким виконанням умов, поданих у завданні до теми твору. Як відомо, будьякий текст містить щонайменше три основні складники: вступ, основна частина (аргументи, приклади), висновок. Кожна 3 названих частин виконує свою функцію й відповідно будується за певною логікою й закономірностями, визначеними функціями тієї чи тієї частини.

Першою частиною будь-якого тексту, зокрема й твору-роздуму, є вступна. Її називають по-різному: вступ, зачин, теза, експозиція, преамбула. Проте відразу важливо визначитися з різницею між вступом і тезою, бо у творі-роздумі може бути й те, і інше. Їхнє співвідношення можна визначити як «підготовка до введення тези» $\mathrm{i}$ «власне теза».

Вступом може вважатися:

- лірична замальовка, що готує емоційне тло для подальшого сприйняття міркувань;

- пафосний, наснажений етюд, який підводитиме до теми, опосередковано вказуючи на позицію, яку автор збирається відстояти;

- опис якоїсь ситуації, яка спонукала мовця до формування певної позиції щодо теми.

Крім наведених, можуть бути й інші варіанти вступу, однак жоден не дорівнюється тезі, адже в них не стверджується ваш погляд на певну тему, проблему чи питання, не з'являється позиція, ідея, яку автор збирається довести 
Методичні аспекти розвитку зв'язного мовлення студентів під час написання творів-роздумів

або спростувати, наприклад, «Ось цю тезу я хочу довести (спростувати, проаналізувати, підтвердити, заперечити).

Теза - це: 1) положення, висловлене в книжці, доповіді, статті тощо, правдивість якого треба довести; 2) положення, що коротко й чітко формулює основну ідею чого-небудь або провідне завдання, що стоїть перед кимсь. У логіці теза - це вихідне положення, що вимагає свого подальшого доведення.

Відповідно до цього зауважимо, що теза - це вже не предмет мовлення, як тема, а швидше - ідея, думка, яку ми розкриваємо, намагаючись його зрозуміти, осмислити з власної позиції.

Під час написання роботи варто розмежовувати поняття «аргумент» $\mathrm{i}$ «приклад», «аргумент» і «факт». Зазначимо, що аргумент - це логічне судження, оформлене мовними засобами, яке служить засобом обгрунтування іншого судження (тези, іншого аргументу). Низку аргументів використовують для ствердження істинності, справедливості, виправданості тези.

Наступний етап - критичний аналіз написаного (переказування) багатьом здається складним завданням: стисло і критично переказати власне висловлення, відкидаючи всі подробиці й деталі, схематично зобразити, написане у творі. Тобто, твір може зазнати суттєвих змін під час його втілення в словесну форму. Під час написання твору необхідно продемонструвати багатство особистого мовлення, навички користування лексичними та граматичними засобами зв'язку речень у тексті. Для того щоб зробити текст більш експресивним, наголошуємо на використанні тропів, риторичних фігур, конструкцій «запитання - відповідь», коли запитуємо самі себе і самі відповідаємо на запитання.

Сьомий етап - перевірка мовного оформлення. Здійснюється після критичного аналізу попереднього варіанту твору та його доопрацювання, проводиться робота, спрямована на вдосконалення мовного аспекту твору: перевіряється грамотність написаного, уточнюються слова, добираються синоніми тощо.

Необхідно також зупинитися на словесних маркерах (вставні слова, й словосполучення, фрази-кліше), які допомагають окреслити логіку творуроздуму, зорієнтує читача в тексті. Розглянемо основні види маркерів.

У мові існує чимало засобів, функцією яких стало орієнтування читача в тексті. Перша група - це маркери фаз (етапів) початку, продовження (розвитку, розгортання) й кінця. У нагоді студентам можуть стати такі фрази-кліше й окремі слова: 1. Вирушаючи в дорогу роздумів над темою.., вважаю за необхідне відразу зазначити, щзо... 2. На початку розмови про ...важливо визначитися з деякими важливими питаннями... 3. Спочатку було б доречно... 4. Хотів би (хотіла б) розпочати свої роздуми над ијєю проблемою з того, щуо... 5. Гадаю не варто 


\section{С. ПОМИРЧА, Н. ГРОМОВА}

Методичні аспекти розвитку зв'язного мовлення студентів під час написання творів-роздумів

зупинятися... 6. Продовжу цей логічний ланцююжок таким твердженням: ... 7. Свої міркування продовжу в такий спосіб... 8. Розгортання подальшої аргументації не можливе без звернення до ... 9. Вихідною позичією для наступних міркувань є думка, щзо ... 10. Наступною позицією, щзо варта уваги (яку не можна зігнорувати) є ... 11. Далі варто звернути увагу на той факт (на таке твердження), що... 12. Послідовність викладу передбачає необхідність звернення ....13. Завершуючи, можу сказати...14. Логіка попередніх міркувань підводить до логічного підсумку (висновку, закінчення).... 15. На закінчення нагадаю , що.... 16. Під кінець твору хочу ще раз наголосити .... 17. Нарешті стає зрозумілим те, що...18. Урешті-решт доходимо висновку, що ...

Другу групу формують слова й фрази, якими мова забезпечила нас, щоб інформувати про своє ставлення до повідомлюваного й указувати на характер того повідомлення, яке йтиме далі (чи це твердження, чи це переконання, чи це аргумент, чи це висновок тощо). Ось низка таких кліше, якими можна ввести тезу: 1. Я вважаю, щуо .... 2. На мою думку .... 3. На моє глибоке переконання.... 4. Переконаний (переконана), щуо важко не погодитись з тим, що.... 5. Цілком справедливим буде твердження, щзо....

6. Мені здається, що .... 7. Як на мене, то .... 8. Без перебільшення можна стверджувати, щьо .... 9. Істинним можна вважати твердження (думку, позииію) про те, що .... 10. Багато хто (людей) вважсає, що ... Не можу не приєднатися до такого погляду. 11. Можливо, багато хто й не погодиться зі мною (моєю позицією, поглядом, твердженням), але з усією впевненістю хочу заявити, щзо .... 12. Вважаю, щу не може бути піддана сумніву позиџія, згідно з якою ..., адже вона трунтована на досвіді багатьох поколінь.

Аргументація висловленої тези також має забезпечуватися відповідними мовними засобами. Ось зразки окремих кліше, які можуть бути взяті на озброєння: 1. Щоб підтвердити свою думку, скажу таке ... 2. Аргументом, що свідчить на користь моєї правоти (виправданості мого погляду, істинності такого погляду на факт, ситуацію, проблему), може бути те, щзо .... 3. Висловлена мною думка цілком закономірна ( справедлива, виправдана, має право на життя) з огляду на те, щуо .... 4. Стверджуючи позицію, згідно з якою ..., хочу навести такий аргумент: .... 5. Свою позиџію, заявлену вище, хотів би (хотіла б) аргументувати низкою міркувань. По-перше, ... По-друге, ... 6. Які ж аргументи можуть бути запропоновані на користь мого погляду (думки, ідеї) стосовно ...? Наведу декілька, як на мій погляд, найпереконливіших. Передусім ... Крім иього ...А ще й те, що ...

Ілюстрування аргументів (доказів, положень), що підтверджують тезу, має також оформлюватися за допомогою певних мовних засобів. Ось деякі з них: 1 .

Професіоналізм педагога: теоретичні й методичні аспекти. - Вип. 12. - Слов'янськ, 2020. 
Методичні аспекти розвитку зв'язного мовлення студентів під час написання творів-роздумів

Наприклад: .... 2. Яскравим прикладом иієї ситуащії може бути історія, яка трапилася зі мною.... 3. За приклад може правити такий випадок .... 4. Проілюструвати наведене вище твердження може такий приклад. 5. Прикладів, які наочно підтверджують запропонований аргумент, безліч. Зупинюся на одному. Якось .... 6. Життя дає нам багато прикладів подібної поведінки людей. 7. Факти історії, як ніщо інше, переконують у виправданості наведеного вище твердження.

Висновок також обслуговується низкою традиційно вживаних словесних формул на зразок: 1. Отже, .... 2. Таким чином, .... 3. Підсумовуючи сказане, хотілося б ще раз наголосити .... 4. Висновком до запропонованих міркувань може бути таке твердження:.... 5. Логіка моӥх міркувань підводить до висновку ... 6. Підсумком мої міркувань стане така думка: ... 7. Проаналізувавши аргументи «за» $i$ «проти», можу стверджувати, щзо .... 8. Завершуючи свій шлях пошуку відповіді на питання, хотілось би підкреслити ...

Якщо дотримуватись цих порад, то висловлення матиме чітку й послідовну структуру, буде логічно організоване.

Під час переписування або остаточного редагування тексту варто не забувати, що розділові знаки на письмі позначають паузи певної тривалості. При цьому для кожного сегмента тексту, відділеного якимось розділовим знаком, характерне певне інтонаційне оформлення.

Висновки. Отже, твір - це оригінальний зв'язний текст, самостійно складений усно чи письмово за певною темою. Уміння писати твір - це вміння переконливо, логічно, образно викласти свої думки.

Основою формування умінь і навичок зв'язного мовлення є сукупність понять із лінгвістики тексту і стилістики, які стали визначальними у сучасній програмі з мови. Для того щоб розвити вміння писати тексти-роздуми, необхідно постійно працювати над формуванням у студентів відчуття семантичних та емоційно-експресивних відтінків слова. А також тих додаткових значень, що випливають 3 контексту, збагачуючи висловлювання змістовою інформацією. Шлях до цього - лінгвістичний аналіз текстів переказів, художніх творів або їхніх фрагментів.

\section{СПИСОК ВИКОРИСТАНИХ ДЖЕРЕЛ}

1. Виготський, Л. (1999). Думка та слово. Москва.

2. Донченко, Т. (2001). Як готувати учнів до переказу. Українська мова і література в школі, 1, 3-4.

3. Ішутіна, O.С. (2018). Формування навичок письма майбутніх учителів початкової школи в професійній підготовці. Професіоналізм педагога: теоретичні й методичні аспекти, 8(1), 109-121. DOI: 10.31865/2414-9292.8(1).2018.153744 
Методичні аспекти розвитку зв'язного мовлення студентів під час написання творів-роздумів

4. Митяй, 3. О. (2012). Семантичні аспекти організації цілісного тексту, Украӥнознавчий альманах, 9, 154-157.

5. Пентилюк, М. (2010). Компетентнісний підхід до формування мовної особистості у євроінтеграційному контексті, Українська мова та література в школі, 2, 2-8.

\title{
METHODICAL ASPECTS OF DEVELOPING STUDENTS' CONNECTED SPEECH WHEN WRITING ESSAYS
}

\author{
Svitlana Pomyrcha \\ Candidate of Philological Sciences, \\ Associate Professor of the Department of Theory and Practice of Primary Education \\ SHEI «Donbas State Pedagogical University» \\ Slaviansk, Ukraine \\ ORCID ID 0000-0003-1636-3239 \\ swetlanapom@gmail.com
}

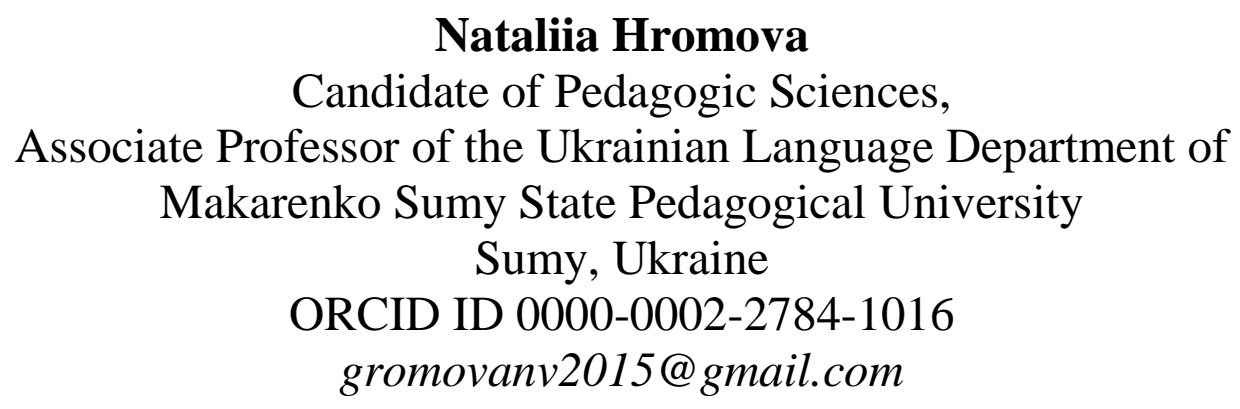

Abstract. The main purpose of teaching the modern Ukrainian language, whose relevance is emphasized in current programs, is to form a nationally conscious and spiritually rich linguistic personality, who has the skills and abilities to use the native language freely and in communicatively justified way. Connected speech is considered in the methodology as a special area of activities in the development of speech - the process of speaking, the activity of a speaker, the product of the activity, text, and expression. Methodical science has already developed a certain system of issues in the study of the development of written language. One of the traditional types of student communication development work is an essay that has a methodical history and a variety of methodical support that allows you to simultaneously assess the level of language, speech and communication competence of future teachers. The interest of linguists in the study of text reflects the tendency of the current stage of the development of linguistics to move from teaching language as an abstract system to exploring its functioning as a means of communication.

The article deals with the recommendations on writing somebody's statements as an essay. These theoretical methodical tips help to consolidate theoretical knowledge in practice, to develop stable skills in writing somebody's expressions according to the clear parameters provided by the conditions for writing this type of creative work.

In the article the author considers the stages of writing aa essay; draws attention to the fact that this type of work enables the assessment of the level of language, speech and communication competence of future teachers at the same time.

The ability to perceive and understand what is heard or read, to present its content, to formulate an opinion accurately, express it in writing can only be formed on the basis of the development of thinking and speech, which is the basis of teaching the modern Ukrainian language in universities.

Професіоналізм педагога: теоретичні й методичні аспекти. - Вип. 12. - Слов'янськ, 2020. 
Методичні аспекти розвитку зв'язного мовлення студентів під час написання творів-роздумів

In the paper it is proved that the basis of developing skills and abilities of connected language is a set of concepts in linguistics of text and stylistics. In order to develop the ability to write creative works, it is necessary to work constantly on forming students' sense of semantic and emotionallyexpressive shades of words. And also those extra values that come out of context, enriching the expression of meaningful information.

Key words: speech development; essay; writing algorithm; text; theme.

\section{REFERENCES}

1. Vygotskyi, L.S. (1999). Thought and a word. Moscow.

2. Donchenko, T. (2001). Yak gotuvaty uchniv do perekazu. Ukrayinska mova i literatura v shkoli, 1, 3-4.

3. Ishutina, O. (2018). Developing writing skills of future primary school teachers in professional training. Profesionalizm pedahoha: teoretychni y metodychni aspekty, 8(1), 109-121. DOI: 10.31865/2414-9292.8(1).2018.153744

4. Mytiai, Z. O. (2012). Semantic aspects of organizing a coherent text. Ukrayinoznavchyi almanah, 9, 154-157.

5. Pentylyuk, M. (2010). Competency-based approach to developing a linguistic personality in European integration context. Ukrayinska mova ta literatura $v$ shkoli, 2, 2-8.

Матеріали надійшли до редакції 27.02.2020 р. 